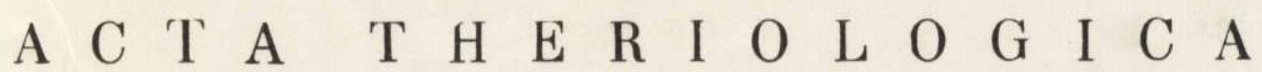

VOL. XVI, 32: $483-504$.

BIAEOWIEŻA

December, 1971

BISONIANA XLVII

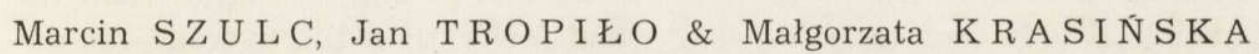

\section{Iressing Percentage and Utility Value of the Meat of European Bison and Domestic Cattle Hybrids}

[With 20 Tables and 1 Fig.]

\begin{abstract}
The dressing percentage and utility value of the meat of European bison and domestic cattle hybrids were defined on the basis of studies of 21 hybrids belonging to three generations: $F_{1}, B_{1}$ and $B_{2}$ Dressing percentage was on an average $56.0 \%(48.5-60.7 \%)$, thus exceeding data for first-class domestic beef cattle. Fore-quarters of hybrids are heavier than the hind ones, this difference being greater than in domestic cattle. The yield of basic elements of the fore quarters of hybrids is greater than that of analogical elements in cattle, and conversely the yield from the hindquarters is lower in hybrids than in cattle. Carcasses of $F_{1}$ hybrids yield a higher average content of meat tissue than those of $\mathrm{B}_{1}$, with a lower bone tissue content. The phenomenon of heterosis characteristic of generation $F_{1}$ is expressed in the stronger muscle development in this generation than in $\mathrm{B}_{1}$ hybrids. The chemical composition of hybrids' meat is similar to that of lean beef, only the intermuscular fat content being lower in hybrids. Organoleptic characterization of the meat of hybrids showed that it is similar in quality to prime beef but is superior to it in respect of its flavour and tastiness and is also tenderer than the meat of European bison.
\end{abstract}

\section{INTRODUCTION}

The present study forms one of the subjects of complex studies on hybrids initiated and coordinated by the Mammals Research Institute, Polish Academy of Sciences, at Białowieża. The chief purpose of the study is to ascertain the value of hybrids as animals for slaughter by defining the basic indices of dressing percentage and certain other characters of the meat obtained. It is to be hoped that in meeting this basic requirement the results of the studies presented will be of both theoretical and practical value. It would appear that the results of the present studies may, and even should, be used as one of the basic indices for analysing the possibility and advantages of initiating the breeding of hybrids as meat-producing animals. 
Only a few reports have been found in literature on similar hybrids of domestic cattle and American bison. For example Logan \& Sylv e s t r e (1950) described experimental work for the purpose of obtaining animals for slaughter for west and north-west Canada, resistant to low temperatures and supplying meat similar in character to beef. P e te rs (1958) showed that the yield from the hind quarters of cattle and bison hybrids is on an average $47.0 \%$ for males and is slightly higher than the analogical value for bison $-46.8 \%$ and lower than the average for domestic cattle - 47.8\%. Similar proportions occurred in females also.

In order to elaborate the subject as fully as possible comprehensive studies were undertaken consisting in: (1) Definition of dressing percentage as a basic index in the meat trade, (2) Definition of yield from quarters and the basic elements (cuts and joints), (3) Definition of the yield of the basic tissues obtained from division and boning of carcasses and basic elements, (4) Definition of yield of the more valuable side products of slaughter, (5) Definition of the contents of basic chemical components of meat, (6) Basic organoleptic evaluation of meat and of some of its culinary products.

\section{MATERIAL AND METHODS}

\section{Material}

Studies were made of 21 European bison and domestic cattle hybrids slaughtered during the period 1968-69 at Białowieża ( $\mathrm{Kr}$ a sińs ka,, 1971). The animals examined belonged to the first generation $F_{1}-5$ animals, the backeross generation $\left(\mathrm{B}_{1}-1 / 4\right.$ European bison $3 / 4$ cattle) -15 animals and $\mathrm{B}_{2}$ generation $(1 / 8$ European bison $7 / 8$ cattle) -1 animal (Table 1). The group of animals consisted od 13 bulls, 6 cows and 2 bullocks, and their age varied within wide limits of 6 months to 9 years.

The animals' weight before slaughter (they were not subjected to the usual fast before slaughter) was from 263 to $1.015 \mathrm{~kg}$.

All the animals were obtained from the experimental reserve of the Mammals Research Institute, Polish Academy of Sciences, at Białowieża, and constituted material used for complex studies. This made it necessary to limit to a certain extent the scope of the examination of several animals, in order to obtain an undamaged skeleton, but did not seriously affect the value of the results obtained.

The majority of the hybrids were killed by a shot into the brain from a shot gun, immediately followed by bleeding the animals from an incision in the cervical blood vessels, using the typical method practised in slaughter of domestic cattle. The blood was collected in containers and weighed. Immediately after the blood had been drained off the slaughtered animals were taken to the slaughterhouse at Białowieża, where they were skinned and dressed in the usual way. All elements removed or excised, and tissues and organs were weighed before being taken to the cold store. The half-carcasses were divided into quarters, their weight defined 
and then placed for 24 hours in a cold store. The quarters were cut up into basic elements and further studies made after 24 hours cooling.

\section{Definition of Dressing Percentage}

Dressing percentage of the hybrids examined was calculated by means of the equation:

$$
W=\frac{m_{t} \cdot 100}{m_{p}}
$$

where $W=$ dressing percentage in $\%, m_{t}=$ weight of half-carcasses in $\mathrm{kg}$, $m_{p}=$ pre-slaughter weight in $\mathrm{kg}$.

Table 1

List and description of hybrids examined.

\begin{tabular}{|r|l|c|c|l|}
\hline No. & Name, sex & $\begin{array}{r}\text { Age, } \\
\text { month }\end{array}$ & Generation & $\begin{array}{c}\text { Date of } \\
\text { slaughter }\end{array}$ \\
\hline 1 & Felon, M & 6 & $\mathrm{~B}_{1}$ & 20 X 69 \\
2 & Fest, M & 6 & $\mathrm{~B}_{1}$ & 22 X 69 \\
3 & Felly, F & 15 & $\mathrm{~B}_{1}$ & 22 X 69 \\
4 & Ferma, F & 17 & $\mathrm{~B}_{1}$ & 29 IX 69 \\
5 & Feld, M & 19 & $\mathrm{~B}_{1}$ & 26 XI 68 \\
6 & Fellach, M & 24 & $\mathrm{~B}_{1}$ & 8 IX 69 \\
7 & Festyn, M & 28 & $\mathrm{~B}_{1}$ & 8 IX 69 \\
8 & Fema, F & 28 & $\mathrm{~B}_{1}$ & 26 VIII 68 \\
9 & Fela, F & 30 & $\mathrm{~B}_{2}$ & 22 X 69 \\
10 & Feg, M & 41 & $\mathrm{~B}_{1}$ & 29 IX 69 \\
11 & Fen, M & 42 & $\mathrm{~B}_{1}$ & 25 XI 68 \\
12 & Feb, M & 43 & $\mathrm{~B}_{1}$ & 25 XI 68 \\
13 & Fey, M & 49 & $\mathrm{~B}_{1}$ & 20 X 69 \\
14 & Fez, M & 52 & $\mathrm{~B}_{1}$ & 23 IX 68 \\
15 & Fetysz, M & 52 & $\mathrm{~B}_{1}$ & 7 X 68 \\
16 & Fakir, M & 63 & $\mathrm{~F}_{1}$ & 4 XI 68 \\
17 & Fenix, M & 66 & $\mathrm{~B}_{1}$ & 4 XI 68 \\
18 & Farad, M & 77 & $\mathrm{~F}_{1}$ & 24 IX 68 \\
19 & Filutka, F & 85 & $\mathrm{~F}_{1}$ & 7 X 68 \\
20 & Filip, M & 94 & $\mathrm{~F}_{1}$ & 11 VI 68 \\
21 & Fama, F & 108 & $\mathrm{~F}_{1}$ & 20 X 69 \\
\hline
\end{tabular}

Pre-slaughter weights of the animals examined were determined either by weighing the live animals or, where this was impracticable, by adding the body weight of the slaughtered animal and the weight of the blood obtained during bleeding.

Pre-slaughter weights were defined with accuracy to $1 \mathrm{~kg}$. The weight of meat half-carcasses (the sum total of weights of both halves) was determined according to the so-called »warm killed weight of half-carcasses « i.e. immediately after they were obtained. The carcasses were prepared in accordance with Polish standard PN 64/A - 82003. The weight of the kidneys, together with their surrounding fat, were included in the weight of half-carcasses, which was defined with accuracy to $1 \mathrm{~kg}$. 


\section{Definition of Yield from Quarters and Basic Elements}

Yield from quarter-carcasses and basic elements was defined in units of weight $(\mathrm{kg})$ and percentage values in relation to the weight of half-carcasses.

Division of half-carcasses into hind- and fore-quarters was carried out in accordance with standard PN 59'A - 82001, in accordance with requirements for beef, cutting between the final and penultimate rib. The quarters were divided into basic elements in accordance with standard PN 64/A - 82003 (beef, basic elements). The following were obtained from jointing quartes: beeffillet, buttock, roastbeef, flank, shank and tail; from fore- quarter: neck - part I, neck - part II shoulder, brisket, breast, ribroast, entrecote and shin (see Fig. 1).

Weights of quarters and main elements were determined immediately after jointing, with accuracy to $0.1 \mathrm{~kg}$.

\section{Definition of Yield of Basic Tissues Obtained from Jointing and Boning of Carcasses and Basic Elements}

Yield of meat tissue (together with connective tissue), fatty tissue and bone was analysed. The weights of all three of these tissues were determined during division and boning of each of the above main elements. Tissue yield was calculated in

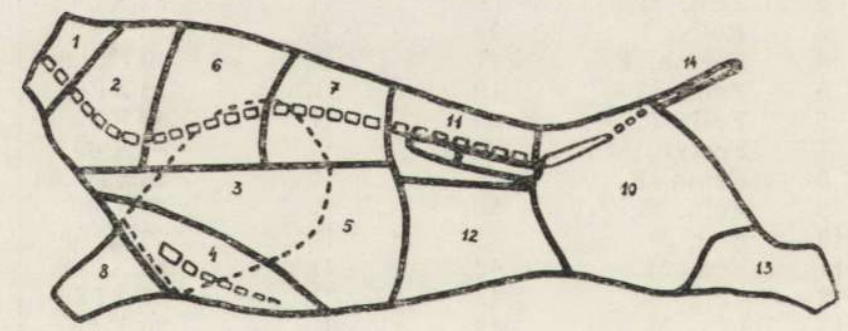

Fig. 1. Diagram of division of half-carcass into quarters and into basic elements. 1 - neck (part I), 2 - neck (part II), 3 - shoulder, 4 - brisket, 5 - breast, 6 - ribroast, 7 - entrecote, 8 - shin, 9 - beeffilet, 10 - buttock, 11 - roastbeef, 12 - flank, 13 - shank, 14 - tail.

percentages in relation to the initial weight of the main element and in relation to the weight of half- and quarter-carcasses. In order to calculate the last two of these values the total weights of each of the tissues under consideration was defined, when isolated from the half-carcass and the hind- and forequarters.

\section{Definition of Yield of More Valuable Side Products of Slaughter}

In examining each hybrid the following were analysed: blood, head, forelegs, hind legs, heart, lungs, liver, kidneys, alimentary tract and skin. Yield of all these elements was defined in units of weight and by percentages in relation to the preslaughter weight of the animal.

By the term »blood " is meant the blood obtained when the carcass was drained.

The head was cut off in a line vertical to the line of the cervical part of the spine, passing between the occiput and first cervical vertebra. 
The term »legs « must be taken to mean the lower parts of the legs. The forelegs were cut off at the metacarpal-carpal articulation, the hindlegs at the metatarsaltarsal joint.

The weight of the heart was defined without the pericardium, and the weight of the kidneys without the tunicles and fat surrounding them.

The weight of the alimentary tract was determined as the joint weight of the rumen, reticulum and omasum, the abomasum and intestines together with their contents and the weight of the skin immediately after its removal from the carcass.

\section{Definition of the Contents of Basic Chemical Components of Meat}

In these studies the contents of components usually identified by basic analysis of meat were defined, namely: water, protein, fat, glycogen and ash. Samples for examination consisted of sections from $m$. quadriceps femoris. In order to ensure the greatest possible degree of uniformity of materials, sections were always taken from the same places, then divided from macroscopically visible elements of connective tissue and fat. The true and final sample for analysis was thus formed by meat tissue. Weight samples were taken from material prepared in this way in order to determine the contents of the above-mentioned components. The arithmetical mean of three results parallel to each other was taken as the result of examination of samples in each case.

Water content was determined by the method of drying 10-gramme samples of meat in an oven at a temperature of $105^{\circ} \mathrm{C}$, in accordance with standard PN 56/A 82110.

Protein content in the meat samples was determined by the micro-Kjeldahl method in a Parnas and Wagner apparatus, in accordance with standard PN 56/A 82113.

Fat content was determined by the Soxhlet method, extracting with ethyl ether, in accordance with standard PN 56/A - 82111.

Glycogen content was determined immediately after dressing the halfcarcasses, using the method elaborated by Szulc (1967). Glycogen contained in a greatly diluted meat broth was determined directly (i.e. without precipitation or hydrolysing to glucose). Quantitative determination was based on the colorimetric method, using the colour reaction of glycogen with free iodine commonly used for qualitative identifications. Measurements were made by means of a Zeiss-Jena "Spekol « spectrophotometer.

Ash content was determined by the typical method after carbonizing weighed samples over a flame and reducing them to ash in a muffle furnace at $450^{\circ} \mathrm{C}$.

\section{Organoleptic Evaluation of Meat and Some of its Culinary Products}

Raw meat, and also boiled, roasted and fried meat, was examined. In the raw state elements and muscles were evaluated organoleptically as follows:

meat from rump - m. quadriceps femoris,

roastbee $\quad-m$. longissimus dorsi,

fillet of beef $-m$. ilio-psoas.

Shoulder steak ( $m$. triceps brachii) was used for evaluation of stewed meat. A piece of rump steak was used for roasting (part of $m$. quadriceps femoris) and for frying - fillet of beef ( $m$. ilio-psoas).

The basic characters of meat which determine its suitability for cooking and 
eating are: colour, smell, taste and flavour, tenderness, succulence. All the above characters were defined comparatively in relation to the analogical characters of the same cuts of beef. Tasting and testing was done by several groups, comparing and calculating average values for the results obtained by the different groups of assessors.

\section{RESULTS AND DISCUSSION \\ 1. Dressing Percentage of Hybrids}

Dressing percentage of all the animals examined varied within limits of $48.5 \%$ to $60.7 \%$, with an average value for the whole group of $56.0 \%$ (Table 2, section 3 ). Assuming that a great majority of the hybrids meet

Table 2

Dressing percentage of hybrids.

\begin{tabular}{|c|c|c|c|c|c|c|c|}
\hline \multirow[b]{2}{*}{ No. } & \multirow{2}{*}{$\begin{array}{l}\text { Pre- } \\
\text { slaughter } \\
\text { weight }\end{array}$} & \multirow{2}{*}{$\begin{array}{c}\text { Dressing } \\
\text { percentage }\end{array}$} & \multicolumn{5}{|c|}{ Weight in relation to warm killed weight of carcass in $\%$} \\
\hline & & & $\begin{array}{c}\text { Hind- } \\
\text { quarters }\end{array}$ & $\begin{array}{c}\text { Fore- } \\
\text { quarters }\end{array}$ & $\begin{array}{c}\text { Perirenal } \\
\text { fatty tissue }\end{array}$ & Kidneys & Total \\
\hline 1 & 286.00 & 58.1 & 46.9 & 51.8 & 0.9 & 0.4 & 100 \\
\hline 2 & 263.00 & 57.9 & 47.3 & 50.5 & 1.8 & 0.4 & 100 \\
\hline 3 & 279.60 & 51.0 & 47.9 & 51.1 & 0.5 & 0.5 & 100 \\
\hline 4 & 284.00 & 54.5 & 46.9 & 51.8 & 0.9 & 0.4 & 100 \\
\hline 5 & 380.00 & 52.0 & 44.6 & 54.5 & 0.5 & 0.4 & 100 \\
\hline 6 & 500.00 & 53.9 & 43.5 & 55.9 & 0.2 & 0.4 & 100 \\
\hline 7 & 540.40 & 52.4 & 44.7 & 54.5 & 0.3 & 0.5 & 100 \\
\hline 8 & 330.00 & 57.9 & 43.4 & 52.0 & 4.1 & 0.5 & 100 \\
\hline 9 & 429.00 & 51.9 & 46.9 & 51.9 & 0.8 & 0.4 & 100 \\
\hline 10 & 552.00 & 59.5 & 43.2 & 56.2 & 0.3 & 0.3 & 100 \\
\hline 11 & 580.00 & 58.1 & 41.8 & 57.6 & 0.4 & 0.3 & 100 \\
\hline 12 & 540.00 & 58.9 & 41.6 & 57.8 & 0.3 & 0.3 & 100 \\
\hline 13 & 675.40 & 54.6 & 40.7 & 58.7 & 0.3 & 0.3 & 100 \\
\hline 14 & 613.00 & 60.7 & 38.8 & 60.8 & 0.0 & 0.4 & 100 \\
\hline 15 & 567.00 & 55.5 & 39.6 & 60.0 & 0.1 & 0.3 & 100 \\
\hline 16 & 841.00 & 57.2 & 42.0 & 54.9 & 2.7 & 0.4 & 100 \\
\hline 17 & 520.00 & 57.0 & 42.0 & 55.6 & 2.1 & 0.3 & 100 \\
\hline 18 & 1015.00 & 55.0 & 38.0 & 61.6 & 0.0 & 0.4 & 100 \\
\hline 19 & 490.00 & 58.1 & 43.4 & 53.9 & 2.3 & 0.4 & 100 \\
\hline 20 & 885.00 & 59.4 & 33.5 & 64.6 & 1.5 & 0.4 & 100 \\
\hline 21 & 532.00 & 48.5 & 44.7 & 54.7 & 0.1 & 0.5 & 100 \\
\hline \multirow{3}{*}{\multicolumn{2}{|c|}{$\begin{array}{l}\text { Avg. for hybrids } \\
\text { Avg. for domestic } \\
\text { cattle class I } \\
\text { Avg. for domestic } \\
\text { cattle class II }\end{array}$}} & Is $\quad 56.0$ & 41.7 & 57.0 & 0.9 & 0.4 & 100 \\
\hline & & tic $\quad 55.0$ & 46.1 & 50.9 & 2.65 & 0.35 & 100 \\
\hline & & tic 52.0 & 46.4 & 51.2 & 2.00 & 0.40 & 100 \\
\hline
\end{tabular}

the requirements laid down for class II cattle for slaughter, in accordance with criteria for domestic cattle, it can be stated that the dressing percentage of hybrids is fairly high. Analogical average dressing percentage for class II domestic cattle (cows, bullocks, heifers, steers, bulls, bull 
calves) are, after K łossowski (1958) (based on numerous sample slaughters), $53.6 \%$ and for these same animals in class $I-56.8 \%$.

Comparison of the values given shows that the average dressing percentage for the hybrids examined was $2.4 \%$ higher then the analogical value for class $I I$ domestic cattle and $0.8 \%$ lower than that for class $I$. It must be added here that according to the regulations of the Central Office of the Meat Industry (1963) the average dressing percentage for cattle is lower than that given by $\mathrm{K} \nmid$ os sow s k i and is as follows: for class I $-55.0 \%$ and for class II $-52.0 \%$. In such case the dressing percentage of European bison hybrids would be proportionately even higher. The fact deserves emphasis here that the hybrids were not subjected to the typical pre-slaughter fast, which had a lowering effect on the results obtained for dressing percentage.

It may thus be accepted that with the pre-slaughter fast recommended for large ruminants the pre-slaughter weights of the hybrids examined

Table 3

Dressing percentage of hybrids depending on age,

\begin{tabular}{|c|c|c|c|}
\hline No. & $\begin{array}{c}\text { Age in } \\
\text { months }\end{array}$ & $\begin{array}{c}\text { Dressing percentage, } \begin{array}{c}o \\
\text { Observed } \\
\text { range }\end{array} \\
\text { Average }\end{array}$ \\
\hline & & $57.9-58.1$ & 58.0 \\
$1-2$ & 6 & $51.0-54.5$ & 52.8 \\
$3-6$ & $15-24$ & $51.9-59.5$ & 56.4 \\
$7-12$ & $28-43$ & $48.5-60.7$ & 56.2 \\
$13-21$ & $49-108$ & 48.5 \\
\hline
\end{tabular}

would be on an average about $6 \%$ lower than those obtained, which would cause an increase in dressing percentage, on an average of about $3.5 \%$.

If the above correction is made for absence of pre-slaughter fast of the hybrids examined, then dressing percentage for the various animals would be from 52.0 to $64.2 \%$, with an average value for the whole group of $59.5 \%$. These values would thus be clearly higher than the analogical ones for domestic cattle qualified as top class.

It is impossible to establish any significant connection between age and dressing percentage in the case of single animals, but there are certain correlations discernible when defining average dressing percentages for different age groups of these same animals (Table 3). Clearly minimum dressing percentages is found for animals from 1 to 2 years old. Differences between the remaining age groups are not significant.

As expected minimum dressing percentage was found in the case of 
cows (Table 4). Differences between the dressing percentages for bulls and bullosks are scarcely significant.

The relation between dressing percentage and the generation of the hybrids could be considered only between generation $F_{1}$ and generation $\mathrm{B}_{1}(3 / 4$ domestic cattle). The data in table 5 show that slightly higher (by $0.5 \%$ ) average dressing percentage was obtained from generation $\mathrm{B}_{1}$ hybrids, but these differences cannot be considered significant.

\section{Dressing Percentage of Fore- and Hind Quarters}

The results given in table 2, sections 4 and 5 show that the dressing percentage for forequarters calculated from ratio to warm carcass weight varied within limits of $50.5 \%$ to $64.6 \%$ (average $57.0 \%$ ).

Table 4

Dressing percentage of hybrids depending on sex.

\begin{tabular}{|l|r|c|r|}
\hline \multirow{2}{*}{ Sex } & $\begin{array}{c}\text { Number of } \\
\text { animals }\end{array}$ & $\begin{array}{c}\text { Dressing percentage, } q \\
\text { Observed } \\
\text { range }\end{array}$ & Average \\
\hline Cows & 6 & $48.5-58.1$ & 53.6 \\
Bulls & 13 & $52.0-60.7$ & 56.6 \\
Castrates & 2 & $57.0-57.2$ & 57.1 \\
\hline
\end{tabular}

Table 5

Dressing percentage of hybrids depending on their generation.

\begin{tabular}{|c|c|c|c|}
\hline \multirow[b]{2}{*}{ Generation } & \multirow{2}{*}{$\begin{array}{l}\text { Number of } \\
\text { animals }\end{array}$} & \multicolumn{2}{|c|}{ Dressing percentage, $\%$} \\
\hline & & $\begin{array}{l}\text { Observed } \\
\text { range }\end{array}$ & Average \\
\hline $\mathrm{F}_{1}$ & 5 & $48.5-59.4$ & 55.6 \\
\hline $\mathrm{B}_{1}$ & 15 & $51.0-60.7$ & 56.1 \\
\hline $\mathrm{B}_{2}$ & 1 & 51.9 & 51.9 \\
\hline
\end{tabular}

The same percentages for hindquarters (without kidneys and their surrounding fat) varied within limits of $33.5-47.9 \%$ (average $41.7 \%$ ). Analogical values for domestic cattle are on an average: forequarters $50.6 \%$ and hindquarters 46.7 ( $\mathrm{P} \mathrm{e} \mathrm{z} \mathrm{a} \mathrm{c} \mathrm{k} \mathrm{i,} \mathrm{1958).} \mathrm{Comparison} \mathrm{of} \mathrm{these}$ data shows that as compared with domestic cattle hybrids are characterized by distinctly greater dressing percentage of fore-quarters (of $6.4 \%$ ) and lower percentage of hindquarters (of $5.0 \%$ ). This is not a favourable phenomenon, as the nutritive value of meat is greater from the hindquarters. 
The effect of the age of hybrids on the dressing percentage of their fore- and hindquarters is illustrated in table 6 . It will be seen that the dressing percentage of forequarters increases with increasing age of the hybrids, while that of the hindquarters decreases.

The dressing percentage of fore- and hindquarters depends to a significant degree on the sex of the hybrids (Table 7). Although in the case of cattle also the sex factor significantly affects the dressing percentage

Table 6

Influence of hybrids age on yield of fore- and hindquarters.

\begin{tabular}{|c|c|c|c|}
\hline \multirow[b]{2}{*}{ Ne. } & \multirow{2}{*}{$\begin{array}{l}\text { Age in } \\
\text { months }\end{array}$} & \multicolumn{2}{|c|}{ Yield of quarters, } \\
\hline & & Fore & Hind \\
\hline $1-2$ & 6 & 51.2 & 47.1 \\
\hline $3-6$ & $15-24$ & 53.3 & 45.7 \\
\hline $7-12$ & $28-43$ & 55.0 & 43.6 \\
\hline $13-21$ & $49-108$ & 59.1 & 40.3 \\
\hline
\end{tabular}

Table 7

Influence of sex on yield of fore- and hindquarters.

\begin{tabular}{|l|r|c|c|}
\hline \multirow{2}{*}{ Sex } & \multirow{2}{*}{$\begin{array}{c}\text { Number of } \\
\text { animals }\end{array}$} & Fore & Hind \\
\cline { 3 - 4 } & & & \\
\hline Cows & 6 & 52.6 & 45.5 \\
Bulls & 13 & 57.3 & 41.9 \\
Castrate & 2 & 55.2 & 42.0 \\
\hline
\end{tabular}

Table 8

Influence of generation on yield of fore- and hindquarters.

\begin{tabular}{|c|r|c|c|}
\hline \multirow{2}{*}{ Generation } & \multirow{2}{*}{$\begin{array}{c}\text { Number of } \\
\text { animals }\end{array}$} & \multicolumn{2}{|c|}{ Yield of quarters, $\%$} \\
\cline { 3 - 4 } & & Fore & Hind \\
\hline $\mathrm{F}_{1}$ & 5 & 57.9 & 40.3 \\
$\mathrm{~B}_{1}$ & 15 & 55.2 & 43.5 \\
$\mathrm{~B}_{2}$ & 1 & 51.9 & 46.9 \\
\hline
\end{tabular}

of fore- and hindquarters, in hybrids these differences are considerably intensified.

The dressing percentage of fore- and hindquarters also depends on the generation of the hybrids (Table 8). This is obvious since European bison 


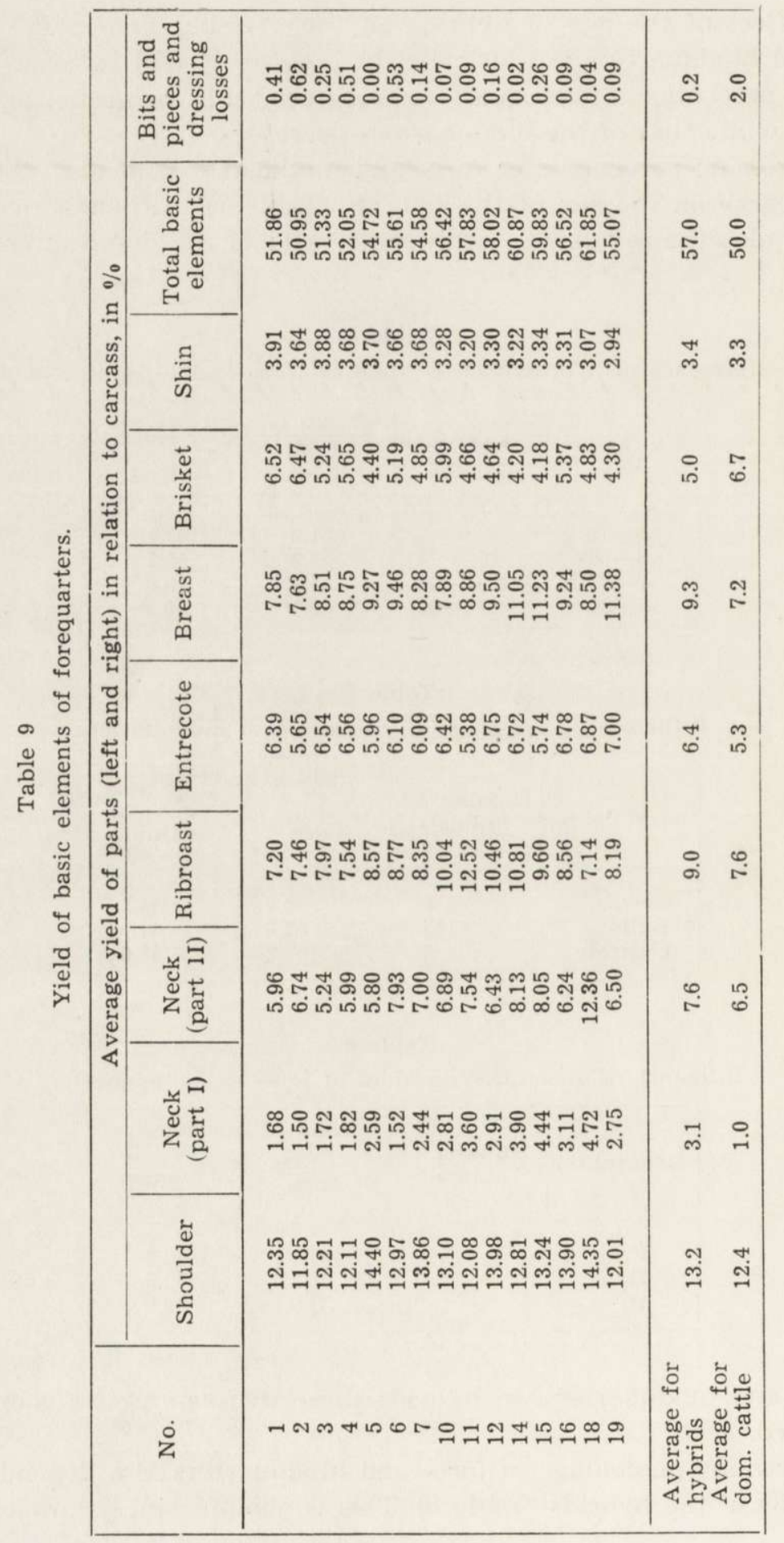


are characterized by far stronger development of the fore part of the body than are domestic cattle.

\section{Percentages of Basic Elements Obtained from Dismembering Carcasses}

Results of determination of the percentages of basic elements are given in tables 9 and 10 for all the hybrids examined. Yield of basic elements was calculated in the form of average values for two paired elements (from left and right half-carcasses) expressed in percentages to the total carcass weight i.e. the sum total of weights of the two halfcarcasses.

Yield for the majority of basic elements of forequarters, excepting the brisket and shin, is greater in hybrids than in domestic cattle. The same

Table 10

Yield of basic elements of hindquarters.

\begin{tabular}{|c|c|c|c|c|c|c|c|c|}
\hline \multirow[b]{2}{*}{ No. } & \multicolumn{8}{|c|}{ Average yield of parts (left and right) in relation to carcass in $\%$} \\
\hline & $\begin{array}{l}\text { Beef- } \\
\text { fillet }\end{array}$ & Buttock & $\begin{array}{c}\text { Rost- } \\
\text { beef }\end{array}$ & Flank & Shank & Tail & $\begin{array}{c}\text { Total } \\
\text { basic } \\
\text { elements }\end{array}$ & $\begin{array}{l}\text { Bits and } \\
\text { pieces } \\
\text { and } \\
\text { dressing } \\
\text { losses }\end{array}$ \\
\hline 1 & 2.58 & 29.48 & 4.59 & 4.59 & 5.90 & 0.37 & 47.52 & 0.21 \\
\hline 2 & 1.91 & 29.29 & 4.84 & 6.06 & 5.58 & 0.27 & 47.96 & 0.47 \\
\hline 3 & 2.66 & 29.45 & 5.14 & 5.32 & 5.46 & 0.29 & 48.31 & 0.11 \\
\hline 4 & 2.52 & 28.23 & 5.79 & 4.44 & 5.29 & 0.44 & 47.38 & 0.06 \\
\hline 5 & 1.94 & 29.04 & 4.87 & 3.94 & 4.95 & 0.41 & 45.16 & 0.12 \\
\hline 6 & 1.73 & 27.00 & 4.80 & 5.03 & 4.61 & 0.34 & 43.54 & 0.32 \\
\hline 7 & 1.64 & 29.04 & 4.92 & 4.71 & 4.60 & 0.33 & 45.24 & 0.04 \\
\hline 10 & 1.72 & 27.54 & 5.02 & 4.77 & 3.87 & 0.40 & 43.32 & 0.19 \\
\hline 11 & 2.21 & 26.36 & 4.90 & 4.62 & 3.69 & 0.30 & 42.08 & 0.00 \\
\hline 12 & 2.13 & 26.98 & 4.32 & 4.10 & 3.87 & 0.40 & 41.79 & 0.03 \\
\hline 14 & 1.37 & 26.32 & 4.20 & 3.74 & 3.06 & 0.37 & 39.07 & 0.04 \\
\hline 15 & 1.59 & 25.34 & 4.87 & 3.93 & 3.70 & 0.39 & 39.78 & 0.13 \\
\hline 16 & 1.80 & 26.17 & 4.87 & 6.02 & 3.76 & 0.40 & 43.03 & 0.36 \\
\hline 18 & 1.36 & 23.98 & 4.94 & 4.04 & 3.42 & 0.38 & 38.12 & 0.00 \\
\hline 19 & 1.84 & 26.66 & 5.56 & 6.00 & 4.00 & 0.40 & 44.47 & 0.37 \\
\hline Average for & & & & & & & & \\
\hline $\begin{array}{l}\text { hybrids } \\
\text { Average for }\end{array}$ & 1.8 & 26.8 & 4.9 & 4.7 & 4.1 & 0.4 & 42.7 & 0.2 \\
\hline dom. cattle & 1.8 & 30.2 & 5.2 & 4.9 & 4.1 & 0.5 & 46.7 & 1.3 \\
\hline
\end{tabular}

data in table 10 show that conversely some of the basic elements of the hind quarters of hybrids, particularly the rump, are characterized by lower yield than in cattle. This is due to the greater development of the fore part of the body and greater yield from forequarters of hybrids than from cattle.

It is clear from tables 9 and 10 that the same factors which determined the yield for the fore- and hind quarters also affect the yield of the basic Acta theriol. 32 
elements of these quarters. Among factors, the effect of which has been described in detail, are: the animals' age, sex and generation. Content of basic tissues in the basic elements and in the whole carcasses of hybrids.

Table 11

Contents of main tissues in basic elements of foreand hindquarters.

\begin{tabular}{|c|c|c|c|c|}
\hline \multirow{3}{*}{$\begin{array}{l}\text { Basic } \\
\text { elements }\end{array}$} & \multirow{3}{*}{$\begin{array}{c}\text { Tissues } \\
\text { examined }\end{array}$} & \multicolumn{3}{|c|}{ Tissue content, in $\%$} \\
\hline & & \multicolumn{2}{|c|}{ Extreme values } & \multirow{2}{*}{ Average } \\
\hline & & Min. & Max. & \\
\hline \multicolumn{5}{|c|}{ Forequarters } \\
\hline Shoulder & $\begin{array}{l}\text { muscles } \\
\text { bones } \\
\text { fat } \\
\text { losses }\end{array}$ & $\begin{array}{r}73.0 \\
16.7 \\
0.0 \\
0.0\end{array}$ & $\begin{array}{r}80.7 \\
22.2 \\
7.7 \\
1.4\end{array}$ & $\begin{array}{r}78.6 \\
19.6 \\
1.4 \\
0.4\end{array}$ \\
\hline $\begin{array}{l}\text { Neck } \\
\text { (part I) }\end{array}$ & $\begin{array}{l}\text { muscles } \\
\text { bones } \\
\text { fat } \\
\text { losses }\end{array}$ & $\begin{array}{r}65.9 \\
15.1 \\
0.0 \\
0.0\end{array}$ & $\begin{array}{r}83.3 \\
-27.5 \\
9.1 \\
9.1\end{array}$ & $\begin{array}{r}78.2 \\
19.3 \\
1.1 \\
1.4\end{array}$ \\
\hline $\begin{array}{l}\text { Neck } \\
\text { (part II) }\end{array}$ & $\begin{array}{l}\text { muscles } \\
\text { bones } \\
\text { fat } \\
\text { losses }\end{array}$ & $\begin{array}{r}68.7 \\
11.3 \\
0.0 \\
0.0\end{array}$ & $\begin{array}{r}88.0 \\
18.8 \\
17.7 \\
3.2\end{array}$ & $\begin{array}{r}83.5 \\
13.2 \\
2.6 \\
0.7\end{array}$ \\
\hline Ribroast & $\begin{array}{l}\text { muscles } \\
\text { bones } \\
\text { fat } \\
\text { losses }\end{array}$ & $\begin{array}{r}71.5 \\
15.0 \\
0.0 \\
0.0\end{array}$ & $\begin{array}{r}85.0 \\
25.9 \\
6.6 \\
2.7\end{array}$ & $\begin{array}{r}78.9 \\
19.2 \\
1.2 \\
0.7\end{array}$ \\
\hline Entrecote & $\begin{array}{l}\text { muscles } \\
\text { bones } \\
\text { fat } \\
\text { losses }\end{array}$ & $\begin{array}{r}63.0 \\
17.3 \\
0.0 \\
0.0\end{array}$ & $\begin{array}{r}77: 6 \\
26.1 \\
18.3 \\
3.4\end{array}$ & $\begin{array}{r}73.3 \\
21.9 \\
4.0 \\
0.4\end{array}$ \\
\hline Breast & $\begin{array}{l}\text { muscles } \\
\text { bones } \\
\text { fat } \\
\text { losses }\end{array}$ & $\begin{array}{r}63.2 \\
14.5 \\
0.0 \\
0.0\end{array}$ & $\begin{array}{r}81.5 \\
30.3 \\
14.3 \\
2.5\end{array}$ & $\begin{array}{r}75.3 \\
20.3 \\
3.7 \\
0.7\end{array}$ \\
\hline Brisket & $\begin{array}{l}\text { muscles } \\
\text { bones } \\
\text { fat } \\
\text { losses }\end{array}$ & $\begin{array}{r}56.4 \\
18.6 \\
0.0 \\
0.0\end{array}$ & $\begin{array}{r}79.5 \\
28.8 \\
22.2 \\
3.1\end{array}$ & $\begin{array}{r}68.2 \\
22.5 \\
8.5 \\
0.8\end{array}$ \\
\hline Shin & $\begin{array}{l}\text { muscles } \\
\text { bones } \\
\text { fat } \\
\text { losses }\end{array}$ & $\begin{array}{r}52.5 \\
36.1 \\
0.0 \\
0.0\end{array}$ & $\begin{array}{r}61.4 \\
47.5 \\
2.6 \\
3.7\end{array}$ & $\begin{array}{r}56.5 \\
41.9 \\
0.3 \\
1.3\end{array}$ \\
\hline & & dquarte & & * \\
\hline Beeffillet & $\begin{array}{l}\text { muscles } \\
\text { fat } \\
\text { losses }\end{array}$ & $\begin{array}{r}82.4 \\
0.0 \\
0.0\end{array}$ & $\begin{array}{r}100.0 \\
16.2 \\
1.4\end{array}$ & $\begin{array}{r}93.9 \\
5.8 \\
0.3\end{array}$ \\
\hline
\end{tabular}


Table 11 (continued)

\begin{tabular}{|c|c|c|c|c|}
\hline \multirow{3}{*}{$\begin{array}{l}\text { Basic } \\
\text { elements }\end{array}$} & \multirow{3}{*}{$\begin{array}{l}\text { Tissues } \\
\text { examined }\end{array}$} & \multicolumn{3}{|c|}{ Tissue content, in $\%$} \\
\hline & & \multicolumn{2}{|c|}{ Extreme values } & \multirow{2}{*}{ Average } \\
\hline & & Min. & Max. & \\
\hline Buttock & $\begin{array}{l}\text { muscles } \\
\text { bones } \\
\text { fat } \\
\text { losses }\end{array}$ & $\begin{array}{r}77.2 \\
13.2 \\
0.0 \\
0.0\end{array}$ & $\begin{array}{r}84.8 \\
17.8 \\
8.0 \\
1.5\end{array}$ & $\begin{array}{r}82.1 \\
15.4 \\
2.2 \\
0.3\end{array}$ \\
\hline Roastbeef & $\begin{array}{l}\text { muscles } \\
\text { bones } \\
\text { fat } \\
\text { losses }\end{array}$ & $\begin{array}{r}56.1 \\
21.0 \\
0.0 \\
0.0\end{array}$ & $\begin{array}{r}76.2 \\
36.2 \\
21.1 \\
2.3\end{array}$ & $\begin{array}{r}66.0 \\
28.2 \\
4.9 \\
0.9\end{array}$ \\
\hline Flank & $\begin{array}{l}\text { muscles } \\
\text { bones } \\
\text { fat } \\
\text { losses }\end{array}$ & $\begin{array}{r}62.8 \\
0.6 \\
0.0 \\
0.0\end{array}$ & $\begin{array}{r}98.0 \\
3.0 \\
34.3 \\
3.9\end{array}$ & $\begin{array}{r}85.6 \\
1.8 \\
11.3 \\
1.3\end{array}$ \\
\hline Shank & $\begin{array}{l}\text { muscles } \\
\text { bones } \\
\text { fat } \\
\text { losses }\end{array}$ & $\begin{array}{r}47.6 \\
41.0 \\
0.0 \\
0.0\end{array}$ & $\begin{array}{r}59.0 \\
52.4 \\
2.4 \\
3.7\end{array}$ & $\begin{array}{r}53.3 \\
45.0 \\
0.5 \\
1.2\end{array}$ \\
\hline Tail & $\begin{array}{l}\text { muscles } \\
\text { bones } \\
\text { fat } \\
\text { losses }\end{array}$ & $\begin{array}{r}23.8 \\
37.5 \\
0.0 \\
0.0\end{array}$ & $\begin{array}{r}62.5 \\
76.2 \\
13.5 \\
8.3\end{array}$ & $\begin{array}{r}37.6 \\
58.6 \\
1.6 \\
2.2\end{array}$ \\
\hline
\end{tabular}

The results of the studies, calculated in the form of average values, are given in table 11. The results of average yields of tissues obtained from boning the basic elements of the hybrids from both fore- and hind quarters point to the relatively high content of meat tissue and relatively low bone content in the basic elements. Bone content in the basic elements of hybrids is distinctly lower than the analogical average values for domestic cattle. The contents of these same tissues (meat, bone and fat) in whole meat carcasses of hybrids are given in table 12 . These data show that the carcasses of hybrids, as compared with those of cattle, are on an average characterized by: higher meat tissue content (together with connective tissue) by $1.2 \%$, fat content $1.2 \%$ higher and bone content $2.6 \%$ lower. Meat tissue, bone and fat contents in most carcasses were subject to fluctuations neither typical nor depending on the age of the hybrids. The sex of the animals was, however, observed to have a distinct influence on the average contents of the above tissues (Table 13). The carcasses of bull hybrids have decidedly the higher meat tissue content and the carcasses of castrated animals maximum fat content.

Fairly distinct regularities were also observed when analysing the effect of the generation of the hybrids on average values of these tissues in their meat carcasses (Table 14). The meat carcasses of hybrids of ge- 
neration $F_{1}$ are characterized by higher average meat tissue content than the carcasses of generation $\mathrm{B}_{1}\left({ }^{3 / 4}\right.$ domestic cattle), which must be explained by the phenomenon of heterosis observed in the first generation

Table 12

Contens of main tissues in carcasses of hybrids.

\begin{tabular}{|c|c|c|c|c|}
\hline \multirow[b]{2}{*}{ No. } & \multicolumn{4}{|c|}{ Tissue content in carcass, in $\%$} \\
\hline & $\begin{array}{l}\text { Muscular } \\
\text { tissue }\end{array}$ & Bones & Fat & Losses \\
\hline 1 & 70.76 & 20.61 & 6.42 & 2.20 \\
\hline 2 & 70.23 & 18.73 & 8.48 & 2.55 \\
\hline 3 & 75.47 & 19.65 & 3.09 & 1.80 \\
\hline 4 & 74.39 & 19.95 & 3.70 & 1.95 \\
\hline 5 & 75.23 & 23.25 & 1.19 & 0.30 \\
\hline 6 & 77.31 & 20.37 & 0.55 & 1.77 \\
\hline 7 & 77.34 & 22.04 & 0.03 & 0.58 \\
\hline 8 & 76.20 & 23.24 & 0.00 & 0.56 \\
\hline 9 & 72.41 & 20.54 & 6.93 & 0.12 \\
\hline 10 & 79.20 & 19.06 & 0.67 & 1.08 \\
\hline 11 & 79.56 & 18.17 & 1.87 & 0.39 \\
\hline 12 & 76.73 & 20.40 & 2.27 & 0.59 \\
\hline 13 & 79.74 & 17.02 & 2.31 & 0.92 \\
\hline 14 & 80.45 & 19.09 & 0.00 & 0.46 \\
\hline 15 & 77.89 & 19.55 & 1.07 & 1.49 \\
\hline 16 & 70.70 & 17.04 & 11.18 & 1.08 \\
\hline 17 & 74.70 & 19.35 & 5.51 & 0.44 \\
\hline 18 & 79.99 & 19.65 & 0.00 & 0.36 \\
\hline 19 & 73.41 & 16.97 & 8.70 & 0.92 \\
\hline 20 & 84.51 & 14.60 & 0.39 & 0.51 \\
\hline 21 & 75.63 & 18.33 & 4.97 & 1.07 \\
\hline $\begin{array}{l}\text { Average for } \\
\text { hybrids }\end{array}$ & 77.1 & 19.0 & 3.0 & 0.9 \\
\hline $\begin{array}{l}\text { Average for } \\
\text { domestic cattle }\end{array}$ & 75.9 & 21.6 & 1.8 & 0.7 \\
\hline
\end{tabular}

Table 13

Influence of hybrids' sex on average tissue content in carcasses.

\begin{tabular}{|l|c|c|c|c|}
\hline Sex & \multirow{2}{*}{$\begin{array}{c}\text { Number of } \\
\text { animals }\end{array}$} & \multicolumn{3}{|c|}{$\begin{array}{c}\text { Tissue content } \\
\text { in carcass, in } \%\end{array}$} \\
\cline { 3 - 6 } & & $\begin{array}{c}\text { Muscular } \\
\text { tissue }\end{array}$ & Bones & Fat \\
\hline Cows & 6 & 74.6 & 19.8 & 4.6 \\
Bulls & 13 & 77.6 & 19.4 & 1.9 \\
Castrates & 2 & 72.7 & 18.2 & 8.3 \\
\hline
\end{tabular}

of hybrids (K r a s ińska, 1967, 1969; Kras ińska \& P u c ek, 1967). Minimum meat tissue content was found in the carcass of the generation $\mathrm{B}_{2}$ hybrids ( $7 / 8$ cattle), but this is not a reliable result as it refers to one 
animal only. The reverse relation occurred in the case of bone. The average content of this tissue was clearly lower in the meat carcasses of generation $\mathrm{F}_{1}$ hybrids.

When the same analysis is made omitting castrates fairly significant changes in results for generation $F_{1}$ are obtained. In this case the average

Table 14

Influence of generation on average tissue content in carcasses.

\begin{tabular}{|c|c|c|c|c|}
\hline \multirow{2}{*}{ Generation } & \multirow{2}{*}{$\begin{array}{c}\text { Number of } \\
\text { animals }\end{array}$} & \multicolumn{3}{|c|}{$\begin{array}{c}\text { Tissue content } \\
\text { in carcass, in } \%\end{array}$} \\
\cline { 3 - 5 } & & $\begin{array}{c}\text { Muscular } \\
\text { tissue }\end{array}$ & Bones & Fat \\
\hline $\mathrm{F}_{1}$ & 5 & 76.8 & 17.3 & 5.0 \\
$\mathrm{~B}_{1}$ & 15 & 76.3 & 20.0 & 2.5 \\
$\mathrm{~B}_{2}$ & 1 & 72.4 & 20.5 & 6.9 \\
\hline
\end{tabular}

Table 15

Yield of more important side products of slaughter.

\begin{tabular}{|c|c|c|c|c|}
\hline \multirow[b]{2}{*}{ Side products } & \multicolumn{4}{|c|}{ Yield in relation to pre-slaughter weight in $\underset{\%}{q}$} \\
\hline & Min. & Max. & Average & $\begin{array}{c}\text { Average in } \\
\text { domestic } \\
\text { catle }\end{array}$ \\
\hline Blood & 1.90 & 4.51 & 3.55 & 4.30 \\
\hline Head & 3.31 & 4.06 & 3.66 & 3.40 \\
\hline Fore legs & 0.61 & 1.15 & 0.88 & 1.40 \\
\hline Hind legs & 0.54 & 1.15 & 0.84 & 1.40 \\
\hline Heart & 0.44 & 0.68 & 0.58 & 0.45 \\
\hline Lungs with trachea & 0.79 & 1.63 & 1.04 & 0.95 \\
\hline Liver & 1.06 & 1.68 & 1.32 & 1.20 \\
\hline Kidneys & 0.16 & 0.26 & 0.21 & 0.25 \\
\hline Alimentary tract & 15.04 & 28.76 & 19.13 & - \\
\hline Skin & 5.71 & 10.41 & 8.20 & 6.30 \\
\hline
\end{tabular}

contents of tissues in generation $\mathrm{F}_{1}$ carcasses are: meat tissue $78.4 \%$, bone $17.4 \%$ and fat $3.5 \%$. These changes can be fully explained by the fact that fat content is normally far higher in the carcasses of castrates.

\section{Yield of More Valuable Side Products of Slaughter}

It is only yield of blood which is marked greater in domestic cattle than in hybrids (Table 15). Kidney yield is also greater, but in this case differences are not significant. Other side products of slaughter are distinguished by average higher productivity in hybrids. 
Analysis of detailed results obtained for different animals shows that such factors as age, sex and generation of hybrids exert an important influence only on yield of the head and skin of hybrids. Head yield was greater in males than females and skin output, increasing proportionately to the animals' age, was also greater in males than females and greater in generation $F_{1}$ than the backcross generation.

\section{Contents of Basic Chemical Components of Meat}

The data in table 16 show that of the components examined the greatest extreme deviations (in relation to average values) are found for

Table 16

Chemical composition of hybrids' meat ( $m$. quadriceps femoris).

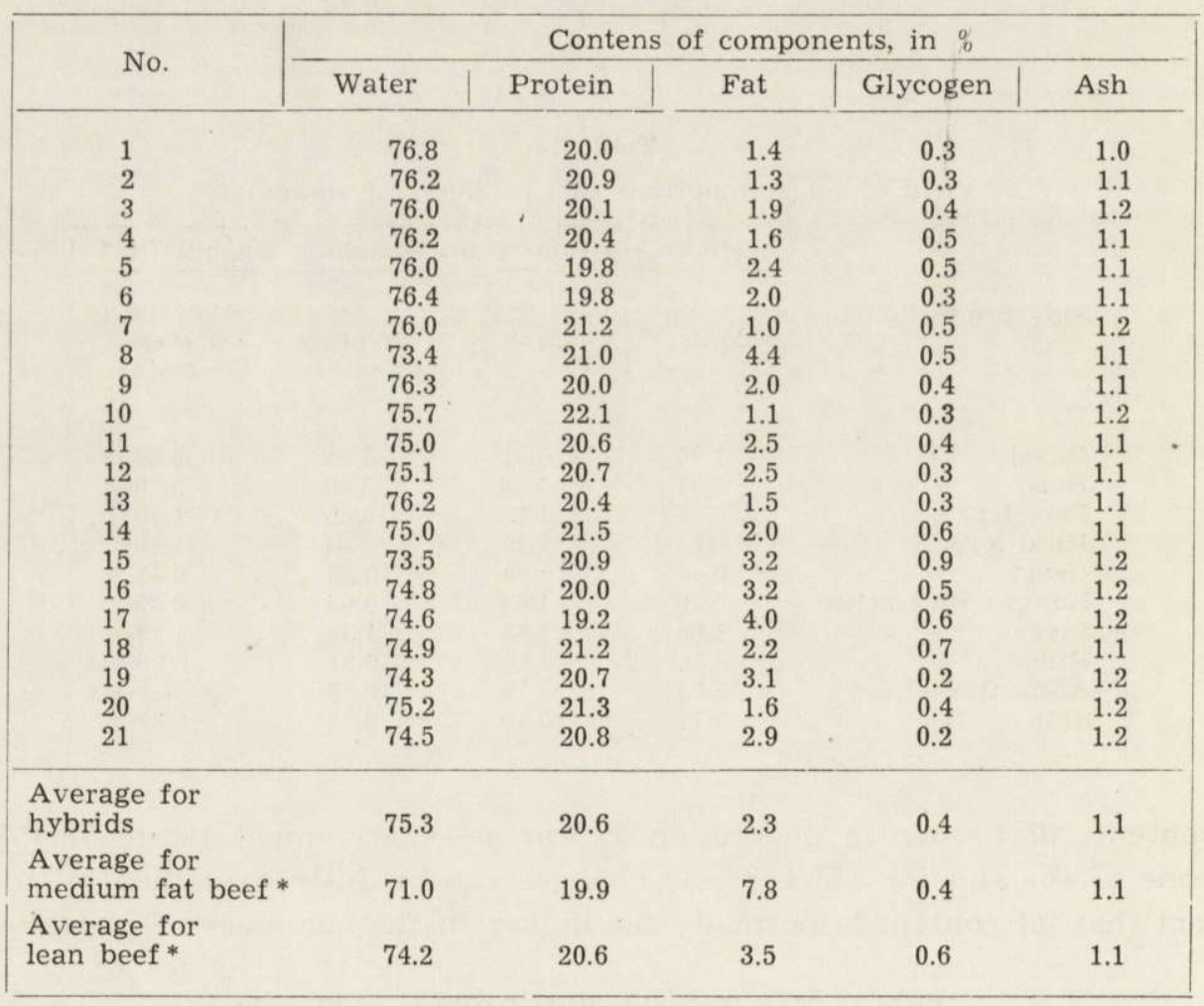

* Acc. to Rudawska-Koprowska, 1954.

fat and glycogen. Fat content depends in hybrids, as in domestic cattle, on a large number of factors such as, for instance: age, sex, feeding etc. The influence of some of these will be considered further. Deviations 
from glycogen content in muscles, varying from $0.2-0.9 \%$, with an average value of $0.4 \%$, can be explained both by individual characters and the differences in the preparation of the hybrids for slaughter, and also in selection of meat samples for determination of glycogen at not always uniforms times after slaughter.

Comparison of the average contents of the components analysed in the muscles of hybrids and domestic cattle shows that the most significant differences relate to fat. $\mathrm{Mm}$. quadriceps femoris in hybrids contain far smaller amounts of intermuscular fat $(2.3 \%)$ than the muscles of medium fat domestic cattle $(7.8 \%)$. In respect of its chemical composition the meat of hybrids can therefore be compared to lean beef. It is, however, an interesing fact there that fat content in whole carcasses of hybrids is on an average $1.2 \%$ higher than in beef carcasses of comparable class of quality (cf. Table 12). The above results show that in hybrids fat is mainly deposited not in the muscles but to a greater degree in the subcutaneous tissue and body cavities.

Table 17

Influence of hybrids' age on chemical composition of meat.

\begin{tabular}{|r|c|c|c|c|c|c|}
\hline \multirow{2}{*}{ No. } & \multirow{2}{*}{$\begin{array}{c}\text { Age in } \\
\text { months }\end{array}$} & \multicolumn{5}{|c|}{ Contens of components, in q } \\
\cline { 3 - 7 } & Water & Protein & Fat & Glycogen & Ash \\
\hline & & & & & & \\
$1-2$ & 6 & 76.5 & 20.5 & 1.4 & 0.3 & 1.05 \\
$3-6$ & $15-24$ & 76.1 & 20.0 & 2.0 & 0.4 & 1.12 \\
$7-12$ & $28-43$ & 75.2 & 20.9 & 2.2 & 0.4 & 1.13 \\
$13-21$ & $49-108$ & 74.8 & 20.7 & 2.6 & 0.5 & 1.17 \\
\hline
\end{tabular}

The low fat content in the muscles of hybrids causes them to be distinguished by high protein content, higher than in medium fat beef, and is thus similar to lean beef.

Also the slightly higher average water content in hybrids' muscles $(75.3 \%)$ is connected with the lower fat content. Glycogen and ash content in the muscles of hybrids and domestic cattle are similar.

Analysis was made of the influence of age, sex and generation of hybrids on the contents of the chemical components examined in their meat. The values given in table 17 show that the hybrids' age has an important effect on contents of water and intermuscular fat. With increasing age the intermuscular fat content systematically increases in hybrids and conversely water content decreases. The interrelation between these two components of meat and their dependence on age is typical in hybrids, as it is in domestic cattle and other animals slaughtered for meat. Ash content increases in the animals' muscles with increas- 
ing age (Table 17), which is natural, as ash content is usually in reverse proportion to water content.

The data presented (Tables 16, 17) do not permit of establishing a significant relation between the hybrids' age and the protein and glycogen contents in their muscles.

The sex of hybrids, like that of domestic cattle, affects fat, water and protein content in their meat and also certain reciprocal interrelations of all these three components (Table 19). The muscles of bull hybrids contain the most protein and water and least fat. Conversely the muscles of castrates are characterized by maximum fat content and thus simultaneously - lowest water and protein content. Muscles in cow hybrids occupy an intermediate position. The results obtained do not

Table 18

Influence of hybrids' sex on chemical composition of meat.

\begin{tabular}{|c|c|c|c|c|c|c|}
\hline \multirow{2}{*}{ Sex } & \multirow{2}{*}{$\begin{array}{c}\text { Number of } \\
\text { animals }\end{array}$} & \multicolumn{5}{|c|}{ Contens of components, in $\%$} \\
\hline & & Water & Protein & Fat & Glycogen & Ash \\
\hline Cows & 6 & 75.1 & 20.5 & 2.7 & 0.4 & 1.15 \\
\hline Bulls & 13 & 75.5 & 20.8 & 1.9 & 0.4 & 1.12 \\
\hline Castrates & 2 & 74.7 & 19.6 & 3.6 & 0.6 & 1.20 \\
\hline
\end{tabular}

Table 19

Influence of generation on chemical composition of meat.

\begin{tabular}{|c|c|c|c|c|c|c|}
\hline \multirow{2}{*}{ Generation } & \multirow{2}{*}{$\begin{array}{l}\text { Number of } \\
\text { animals }\end{array}$} & \multicolumn{5}{|c|}{ Contens of components, in $\%$} \\
\hline & & Water & Protein & Fat & Glycogen & Ash \\
\hline $\mathrm{F}_{1}$ & 5 & 74.7 & 20.8 & 2.6 & 0.4 & 1.18 \\
\hline $\mathrm{B}_{1}$ & 15 & 75.5 & 20.6 & 2.2 & 0.4 & 1.13 \\
\hline $\mathrm{B}_{2}$ & 1 & 76.3 & 20.0 & 2.0 & 0.4 & 1.10 \\
\hline
\end{tabular}

permit of determining a typical significant relation between the hybrids' sex and glycogen and ash contents in their meat.

The effect of the given generation of hybrids on the composition of their meat is shown in table 19. Only generation $F_{1}$ and $B_{1}$ could be analysed, generation $F_{1}$ not being fully representative as it consisted solely of older animals. While taking this fact into consideration it can however be said that the meat of the generation $F_{1}$ hybrids examined was characterized by lower water content and slightly higher protein, fat and ash contents than the meat of generation $B_{1}$, but these differences are not great. 


\section{Organoleptic Description of the Meat of Hybrids and Its Culinary Products}

The results of evaluation of the raw meat of hybrids and some of its culinary products are set out in table 20. In examining the basic organoleptic characters of the raw meat of hybrids which determine its suitability for culinary purposes and the characters of the various cuts and joints which determine its value as food, it can be stated that in respect of colour, smell, tenderness and succulence hybrids' meat is similar to beef. All those tasting the various products, however, agreed that those made from hybrids' meat, regardless of the age, sex and generation of animals, had more flavour than the corresponding products made from beef. The fact deserves emphasis that although dishes made from the meat of hybrids have a special flavour, there is no taste or smell of game. It must also be emphasised that as compared with game, in particular the meat of European bison, the meat of hybrids is far more tender, which permits of a relatively short period of hanging after killing and considerable reduction in cooking time.

It may be assumed that the special flavour of hybrids' meat, as compared with beef, is to a great degree due to the semi-natural feeding habits of these animals (cf. D e h n el, 1960; K r a s i ńs k a, 1963, 1967).

One of the most outstanding chefs in Poland - Wiesław M a tc zak of Jabłonna - tested and gave his opinion on the suitability for culinary purposes of the meat of hybrids from Białowieża. He found that meat from the first generation hybrids has a slightly game flavour. $\mathrm{He}$ considered the meat of hybrids of both generations, from which he made a variety of dishes, as extremely tasty and eminently suitable for culinary purposes.

\section{SUMMARY OF RESULTS}

The results of the studies presented permit of stating that hybrids of generation $F_{1}$ and $B_{1}$ form excellent material as meat. This statement is justified in the first place by the high dressing percentage of hybrids, higher than that of beef cattle with which it was compared. In the second place the meat yield in relation to bone is higher in the carcasses of hybrids than in similar beef carcasses.

The contents of the basic chemical components of hybrids' meat are similar to the analogical values for beef. Compared with beef, however, 'hybrids' meat is characterized by averagely lower intermuscular fat content and consequently higher protein content. It may therefore be considered that hybrids' meat is more digestible, and thus dietetically more suitable even than medium fat beef. 


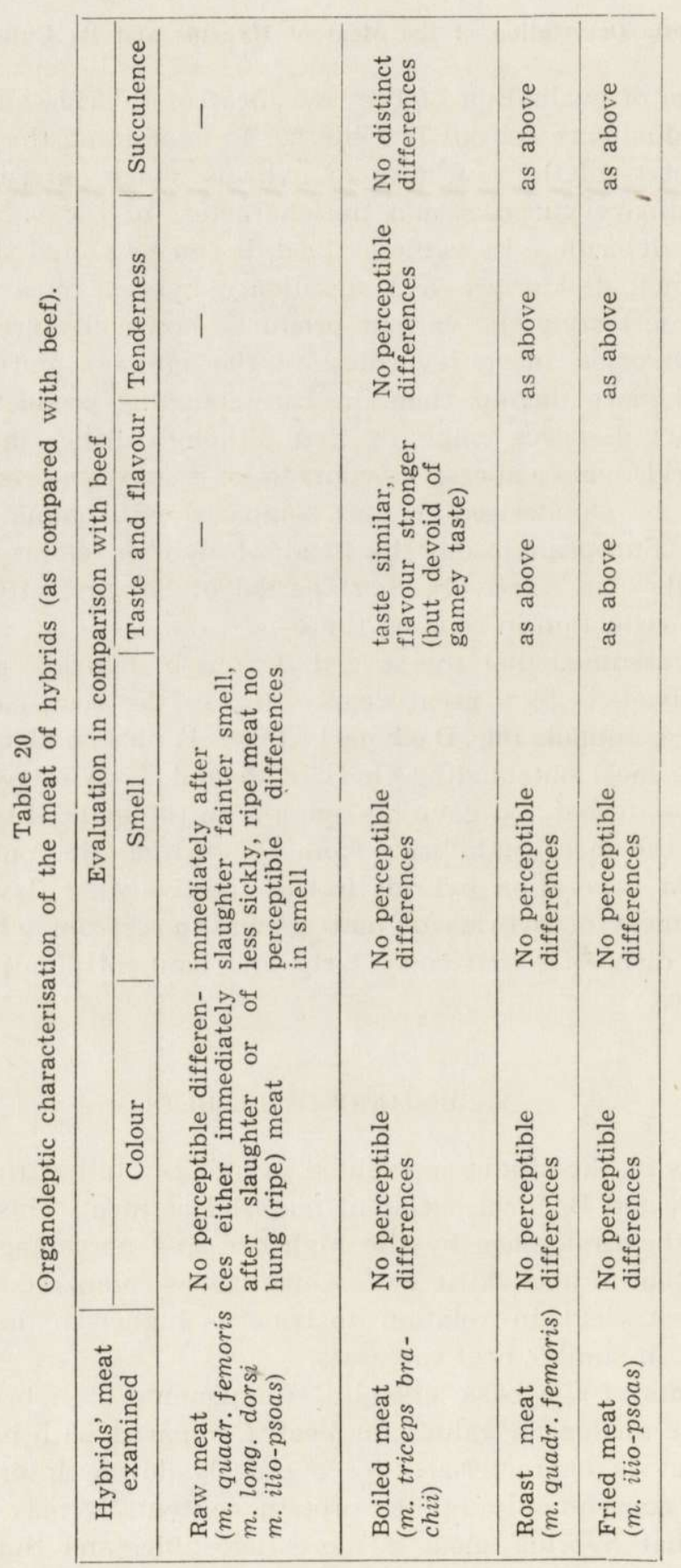


Evaluation of the basic organoleptic characters shows that hybrids' meat is very similar to beef. Hybrids' meat is, however, characterized by greater flavour, which enhances its tastiness and thus its value as food as compared with beef.

The results obtained justify the statement that hybrids' meat is a high quality raw product and that the dishes made from it would enjoy great popiularity among consumers as unique products with a flavour and tastiness rarely encountered nowadays.

\section{REFERENCES}

1. Centrala Przemysłu Mięsnego, 1962: Przepisy wewnętrzne Nr 20 Wyd. Przem. Lekkiego i Spoż.: 1-424. Warszawa.

2. Dehnel A. 1960: Beobachtungen über Zusammenleben von Wisent und Hausrind. Acta theriol., 3, 14: 314-317.

3. Experimental Farm Manyberries, Alta., 1963: Research report 1959-1961, Ottawa.

4. Kłossowski T., 1958: Mięso i przetwory mięsne, towaroznawstwo. Państw. Wyd. Gospod.: 1-396. Warszawa.

5. Krasińska M., 1963: Weitere Untersuchungen über Kreuzungen des Wisentes Bison bonasus (L inna e us, 1758) mit dem Hausrind Bos taurus dom. Li n n a e s, 1758. Acta theriol., 7, 14: 301-310.

6. K ra sińska M., 1967: Crosses of wisent and domestic cattle V. Acta theriol., 12, 5: $67-80$.

7. Krasińska M., 1969: The postnatal development of $F_{1}$ hybrids of the European bison and domestic cattle. Acta theriol., 14, 7: 69-117.

8. Krasińska \& Pucek Z., 1967: The state of studies on hybridisation of European bison and domestic cattle. Acta theriol., 12, 27: 385-389.

9. Logan V. S. \& Sylvestre P. E., 1950: Hybridisation of domestic beef cattle and buffalo. Experim. Farms Serv. Dept. Agric., Ottava, Ontario: 1-7.

10. Polski Komitet Normalizacyjny, 1956: Mięso i przetwory mięsne, oznaczanie zawartości wody PN-56/A-82110.

11. Polski Komitet Normalizacyjny, 1956: Mięso i przetwory mięsne, oznaczanie zawartości tłuszczu, PN-56/A-82111.

12. Polski Komitet Normalizacyjny, 1956: Mięso i przetwory mięsne, oznaczenie zawartości białka, PN-56/A-82113.

13. Polski Komitet Normalizacyjny, 1959: Mięso w tuszach i półtuszach i ćwierćtuszach, PN-59/A-82001.

14. Polski Komitet Normalizacyjny, 1964: Wołowina - części zasadnicze, PN-64/A-82000 .

15. Peters H. F., 1958: A feedlot study of bison, cattalo and hereford calves. Canad. J. Animal Scien., 38: 87-90.

16. Pezacki W., 1958: Artykuły rzeźne zasadnicze i uboczne. Wyd. Przem. Lekkiego i Spożywczego: 1-462. Warszawa.

17. Rudawska-Koprowska J., 1954: Tablice wartości odżywczych produktów spożywczych: 1-214. Warszawa.

18. Szulc M., 1967: Szybka metoda kolorymetrycznego oznaczania glikogenu w tkance mięśniowej. Medycyna Wet., 4: 236-238. 
Marcin SZULC, Jan TROPIŁO i Małgorzata KRASIÑSKA

WYDAJNOSĆ POUBOJOWA ORAZ WARTOSC UŻYTKOWA MIĘSA HYBRYDÓW
ŻUBRA I BYDEA DOMOWEGO

\section{Streszczenie}

Zbadano wydajność poubojową oraz wartość użytkową mięsa hybrydów żubra i bydła domowego. Materiał składał się z 21 hybrydów pokolenia $F_{1}, B_{1}(3 / 4$ bydła domowego) i $\mathrm{B}_{2}(7 / 8$ bydła domowego) wyhodowanych przez Zakład Badania Ssaków PAN w Białowieży, a ubijanych w latach 1968-1969 (Tabela 1). Ubój hybrydów następował przez strzelanie $\mathrm{z}$ broni kulowej w mózgowie i bezpośrednio po tym wykrwawianie. Skórowanie, obróbkę poubojową zwierząt oraz podział na półtusze i ćwierćtusze wykonywano w sposób typowy, stosowany powszechnie przy uboju bydła domowego. Podział półtusz i ćwierćtusz mięsnych na części zasadnicze oraz ich dysekcję i obliczanie analizowanych wskaźników wykonywano zgodnie z obowiązującymi w Polsce przepisami - normami technologicznymi.

Wydajność poubojowa hybrydów wahała się w granicach od $48,5 \%$ do $60,7 \%$ (średnio $56,0 \%$ ). Jest więc wyższa niż średnia dla bydła domowego, zakwalifikowanego nawet do pierwszej klasy jakościowej (Tabela 2). Cwierćtusze przednie są u hybrydów znacznie cięższe niż tylne. W stosunku do tzw. „wagi bitej ciepłej” wydajność ćwierćtusz przednich wynosi średnio $57 \%$, a ćwierćtusz tylnych $41,7 \%$. Różnice między ciężarami ćwierćtusz przednich i tylnych są więc u hybrydów większe niż u bydła domowego.

Wpływ wieku, płci i pokolenia krzyżówek na wydajność poubojową oraz na wydajność ćwierćtusz przednich i tylnych przedstawiono w tabelach $3-8$.

Wydajność części zasadniczych wycinanych z ćwierćtusz przednich hybrydów (Tabela 9) jest średnio wyższa niż tych samych elementów bydła domowego. Odwrotnie, wydajność części zasadniczych z ćwierćtusz tylnych (Tabela 10) jest u hybrydów niższa niż u bydła.

Tusze hybrydów cechują się stosunkowo dużą wydajnością (wyższą niż u bydła domowego) tkanki mięśniowej, natomiast stosunkowo mniejszą zawartością kości (Tabela 11, 12).

Wydajność znacznej większości ubocznych produktów rzeźnych jest u hybrydów wyższa niż u bydła domowego (Tabela 15).

Skład chemiczny mięsa hybrydów jest zbliżony do wołowiny chudej. Jednakże zawartość tłuszczu śródmięśniowego jest w mięsie hybrydów wyraźnie niższa (Tabela 16).

Ocena organoleptyczna mięsa surowego hybrydów oraz niektórych jego przetworów kulinarnych wskazuje na znaczne podobieństwo do wysokogatunkowej wołowiny i jej analogicznych przetworów (Tabela 20). Jednakże w porównaniu z wołowiną, mięso hybrydów cechuje się większą aromatycznością, bez zapachu i posmaku dziczyzny.

Reasumując można stwierdzić, hybrydy stanowią cenny materiał rzeźny, a ich mięso jest produktem pożywnym, o dużej smakowitości, a więc o bardzo wysokiej wartości spożywczej.

Accepted, September 10, 1971.

Warsaw Agricultural University, Department of Hygiene of Animal Products, Warszawa, Zamoyskiego 15.
Polish Academy of Sciences, Mammals Research Institute, Białowieża, Poland. (M. Krasińska only). 